\title{
Saphenous vein composite graft based on the left internal thoracic artery: A vein by any other name!
}

\author{
Gaetano Paone, MD, MHSA
}

\author{
From the Division of Cardiac Surgery, Henry Ford Hospital, Detroit, Mich. \\ Disclosures: Author has nothing to disclose with regard to commercial support. \\ Received for publication March 12, 2018; accepted for publication March 19, 2018; available ahead of print April \\ 22, 2018. \\ Address for reprints: Gaetano Paone, MD, MHSA, Division of Cardiac Surgery, Henry Ford Hospital, 2799 W \\ Grand Blvd, Detroit, MI 48202 (E-mail: gpaone1@hfhs.org or gpaone1@comcast.net). \\ J Thorac Cardiovasc Surg 2018;156:995-6 \\ $0022-5223 / \$ 36.00$ \\ Copyright (C) 2018 by The American Association for Thoracic Surgery \\ https://doi.org/10.1016/j.jtcvs.2018.03.060
}

Use of the left internal thoracic artery (LITA) to bypass the left anterior descending coronary artery provides a longrecognized survival benefit in coronary artery bypass grafting surgery. ${ }^{1,2}$ Less consensus exists regarding the choice of conduit for targets in addition to the left anterior descending coronary artery. In this issue of the Journal, Chang and colleagues $^{3}$ present an interesting small randomized study in 2 groups of 13 patients each, seemingly focused on comparing results between the use of upper and lower leg saphenous vein segments as components of a LITA-tosaphenous vein composite graft.

Aside from smaller luminal diameters in the lower leg segments, both the reported histologic and immunohistochemical findings and the excellent early and 1-year graft patency rates were similar between the groups. This study is not, however, simply about the location of origin of the vein segment. The surgical approach described includes an upper or lower leg saphenous vein harvested with a notouch technique, fashioned into a composite Y-graft with the LITA, passively dilated by LITA inflow, and used in a sequential fashion during off-pump multivessel coronary artery bypass grafting. Discounting considerations of the quality of the vein, the arterial target, and the technical proficiency of the surgeon, is there some hierarchy of benefit to the multiple steps involved in this process? ${ }^{4}$

A number of previous reports, including from the same group, have championed what are referred to as "no-touch" and "minimally manipulated" vein harvesting techniques. $5-9$ Is this vein harvesting technique then the critical step? Do we need to know how much touch is too much touch? Saphenous vein is now procured with an endoscopic vein harvesting technique in more than $90 \%$ of cases. ${ }^{10}$ This broad adoption of endoscopic vein harvesting has been associated with a very real decrease in harvest site wound complications, the true incidence and associated morbidity of which was likely much higher than previously acknowledged or reported. Even granting that earlier concerns for graft patency with endoscopic vein harvesting may not

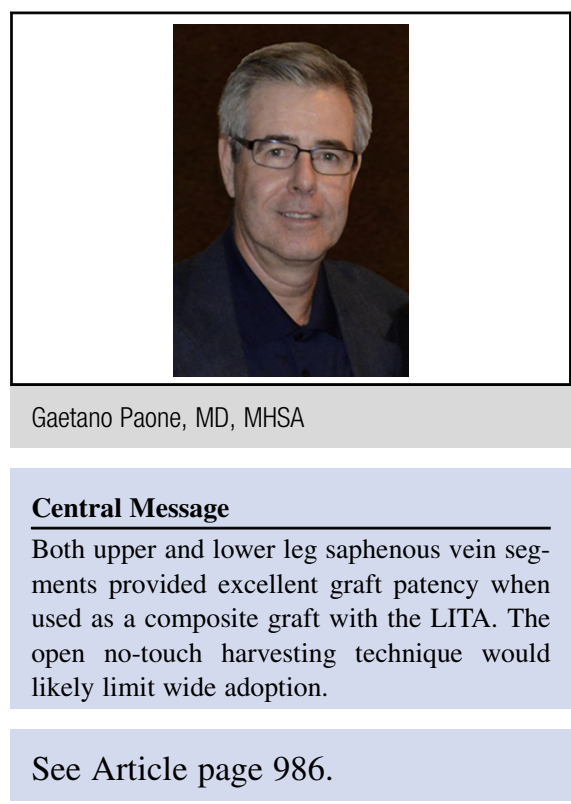

yet be fully adjudicated, I doubt there would be much enthusiasm for a return to routine open vein harvesting. ${ }^{11,12}$

Further, and despite growing recommendations to increase the use of multiarterial grafting, ${ }^{13-15}$ in a recent Society of Thoracic Surgeons Adult Cardiac Surgery Database report, bilateral internal thoracic artery and radial artery conduits were used in only $4.9 \%$ and $5.0 \%$ of cases, respectively. ${ }^{10}$ This, then, would appear to present an opportunity to obtain patency rates and outcomes consistent with the advantages of multiarterial grafting more directly by increasing the use of multiarterial grafting.

Chang and colleagues ${ }^{3}$ are to be commended for their comprehensive and painstaking analysis of saphenous vein properties, their dedication to this technique, and the quality of their results. Longer term follow-up in a larger cohort of patients is needed; even with that, however, wide adoption of this approach seems unlikely. We can certainly harvest a saphenous vein more carefully (and we should), and we can sew a saphenous vein to the LITA (and we could)—but it is, nonetheless, still a saphenous vein.

\section{References}

1. Loop FD, Lytle BW, Cosgrove DM, Goormastic M, Williams GW, Golding LA, et al. Influence of the internal-mammary-artery graft on 10-year survival and other cardiac events. N Engl J Med. 1986;314:1-6.

2. Hillis LD, Smith PK, Anderson JL, Bittl JA, Bridges CR, Byrne JG, et al. 2011 ACCF/AHA guideline for coronary artery bypass graft surgery: a report of the 
American College of Cardiology Foundation/American Heart Association task force on practice guidelines. Circulation. 2011;124:e652-735. Erratum in: Circulation. 2011;124:e957.

3. Chang HW, Hwang HY, Seo JW, Kim KB. Lower versus upper leg saphenous vein composite grafts based on the left internal thoracic artery: a randomized study. J Thorac Cardiovasc Surg. 2018;156:986-94.e2.

4. Deb A, Souza DS, Fremes SE. Composite vein grafting: is it a "Y's" decision? J Thorac Cardiovasc Surg. 2015;149:494-5.

5. Hwang HY, Kim MA, Seo JW, Kim KB. Endothelial preservation of the minimally manipulated saphenous vein composite graft: histologic and immunohistochemical study. J Thorac Cardiovasc Surg. 2012;144:690-6.

6. Kim YH, Oh HC, Choi JW, Hwang HY, Kim KB. No-touch saphenous vein harvesting may improve further the patency of saphenous vein composite grafts: early outcomes and 1-year angiographic results. Ann Thorac Surg. 2017;103: 1489-97.

7. Samano N, Geijer H, Bodin L, Arbeus M, Mannion JD, Dashwood M, et al. The no-touch saphenous vein graft in elderly coronary bypass patients with multiple comorbidities is a promising conduit to substitute the left internal thoracic artery. J Thorac Cardiovasc Surg. 2017;154:457-66.e3.

8. Hwang HY, Lee KH, Han JW, Kim KB. Equivalency of saphenous vein and arterial composite grafts: 5-year angiography and midterm clinical follow-up. Ann Thorac Surg. 2016;102:580-8.

9. Souza DS, Johansson B, Bojö L, Karlsson R, Geijer H, Filbey D, et al. Harvesting the saphenous vein with surrounding tissue for $\mathrm{CABG}$ provides long-term graft patency comparable to the left internal thoracic artery: results of a randomized longitudinal trial. J Thorac Cardiovasc Surg. 2006;132:373-8.

10. The Society of Thoracic Surgeons. Adult Cardiac Surgery Database, Harvest 3 October 2017. Chicago: The Society; 2017.

11. Windecker S, Kolh P, Alfonso F, Collet JP, Cremer J, Falk V, et al. 2014 ESC/ EACTS guidelines on myocardial revascularization: The task force on myocardial revascularization of the European Society of Cardiology (ESC) and the European Association for Cardio-Thoracic Surgery (EACTS) developed with the special contribution of the European Association of Percutaneous Cardiovascular Interventions (EAPCI. Eur Heart J. 2014;35:2541-619.

12. Ouzounian M, Hassan A, Buth KJ, MacPherson C, Ali IM, Hirsch GM, et al. Impact of endoscopic versus open saphenous vein harvest techniques on outcomes after coronary artery bypass grafting. Ann Thorac Surg. 2010;89:403-8.

13. Aldea GS, Bakeen FG, Pal J, Fremes S, Head SJ, Sabik J, et al; Society of Thoracic Surgeons. The Society of Thoracic Surgeons clinical practice guidelines on arterial conduits for coronary artery bypass grafting. Ann Thorac Surg. 2016;101:801-9.

14. Schwann TA, Tatoulis J, Puskas J, Bonnell M, Taggert D, Kurlansky P, et al. Worldwide trends in multi-arterial coronary artery bypass grafting surgery 2004-2014: a tale of 2 continents. Semin Thorac Cardiovasc Surg. 2017;29:273-80.

15. Locker C, Schaff HV, Daly RC, Dearani JA, Bell MR, Frye RL, et al. Multiple arterial grafts improve survival with coronary artery bypass graft surgery versus conventional coronary artery bypass grafting compared with percutaneous coronary interventions. J Thorac Cardiovasc Surg. 2016;152:369-79.e4. 